\title{
Pembiayaan Berbasis Jual Beli dan Kinerja Bank Umum Syariah di Indonesia
}

\author{
Oktaviani Rita Puspasari \\ (Oktavianipuspasari@gmail.com)
}

Universitas Kuningan

\begin{abstract}
This study examine how trade basis financing products which are : murabahah and istishna has an effect to the Islamic Bank performance in Indonesia which meassured by profitability, then the profitability proxied by ROA (return on asset). The sample selection method is purposive sampling and obtained eleven Islamic bank in 5 years period observation with 53 data are being sampled. Multiple regression analysis is used to analyze the data. The results shows that volume of murabahah financing product has negative effect also has no signifficant effect to Islamic Bank performances, istishna' financing has positive and significant effect to the Islamic bank performance in Indonesia, while salam financing have no balance anymore on the total Islamic Bank financing with many internal and external factors which affected, as well as trade basis financing products has no significant effect to the Islamic Bank Performance.

Keyword: A Volume of trade basis financing, murabahah, Salam, Istishna, Islamic Bank Performance.
\end{abstract}

\section{PENDAHULUAN}

Pemahaman masyarakat atas bunga bertransaksi dengan menghindari elemen (interest) serta modal yang hasilnya telah ditentukan di awal (predetermined return) riba(bunga) seperti yang terdapat pada bank konvensional. Hal ini yang menyebabkan merupakan riba yag dilarang oleh agama Islam menjadikan minat masyarakat perbankan syariah dijadikan sebagai suatu terhadap institusi-institusi syariah meningkat, tidak terkecuali sektor perbankan syariah (prabowo, 2009). Perbankan syariah dapat memberikan solusi dengan produk dan layanannya bagi masyarakat yang menginginkan kemudahan acuan atas berkembangnya ekonomi syariah, semakin pesat perbankan syariah dijadikan sebagai indikator bahwa perekonomian syariah berhasil tumbuh. Kondisi ini dirasa cukup membebani, karena bank syariah hanyalah salah satu unsur pendukung diantaranya banyaknya sektor pendukung 
perekonomian syariah lainnya. Oleh karena posisinya sebagai indikator utama dalam perkembangan ekonomi syariah, pengawasan serta evaluasi yang berkelanjutan terhadap kinerja dan perkembangan perbankan syariah khususnya di Indonesia harus selalu dilakukan.

Berkaitan dengan fungsinya sebagai lembaga intermediary keuangan yang memiliki kegiatan utama menghimpun dana serta menyalurkan kembali dalam berbagai skema pembiayaan yang disesuaikan dengan jenis basis perjanjiannya. Pembiayaan yang menjadi andalan dan ciri khas bank syariah adalah pembiayaan berbasis bagi hasil yaitu mudharabah dan musyarakah. Namun porsi dari jenis pembiayaan ini justru malah masih lebih kecil dibandingkan dengan pembiayaan murabahah. Pembiayaan berbasis jual beli ini menjadi fenomena karena porsinya yang sangat besar dibandingkan jenis pembiayaan lain yang disalurkan. Seperti yang dikutip dari Laporan Perkembangan Keuangan Syariah Tahun 2013, secara umum penyaluran pembiayaan perbankan syariah masih didominasi oleh akad murabahah. Pada periode laporan pembiayaan murabahah tumbuh $25,6 \%$ (yoy), sehingga menempati pangsa $60,0 \%$ dari total pembiayaan BUS (Bank Umum Syariah) dan UUS (Unit
Usaha Syariah). Sementara pada pembiayaan BPRS pangsa akad murabahah mencapai 80,3\%. Pemanfaatan akad-akad lain dalam pembiayaan berkembang secara dinamis, khususnya pada kelompok BUS dan UUS. Hal ini perlu menjadi perhatian khusus bagi berbagai kalangan karena prakteknya kecenderungan ini terjadi tidak hanya di Indonesia melainkan di beberapa Bank Islam di negara-negara seperti Malaysia, Bahrain, Kuwait, Dubai yang ketika dirata-rata untuk skema murabahah mencapai 70\%( Lathif, 2010).

Berbagai kritik dilontarkan terkait dengan dominasi pembiayaan murabahah, bahkan banyak yang menjuluki bank syariah sebagai"bank murabahah"(Lathif,2012). Pembiayaan murabahah memang cenderung memiliki risiko yang lebih kecil dan lebih aman bagi shareholder, selain itu sebagai suatu bentuk natural certainty contracts yaitu perjanjian yang menyebutkan dengan jelas berapa keuntungan yang diinginkan untuk diperoleh membuat praktek pelaksanaannya lebih mudah dan cepat dipahami baik oleh praktisi bank maupun masyarakat. Selain itu dugaan modifikasi dari praktek murabahah serta penyimpangan dari konsep dasar murabahah dalam fikih muamalat klasik juga mendasari banyaknya kritik tersebut. 
Pembiayaan berbasis jual beli yang lain yaitu salam dan istishna juga ditawarkan dan diaplikasikan pada bank syariah. Salam sebagai suatu jenis pembiayaan yang berbeda hanya dari sisi pembayaran di muka dibandingkan konsep murabahah. Pembiayaan dengan akad salam sebenarnya diakui eksistensinya di perbankan syariah. Data statistik perbankan syariah yang dipublikasikan oleh Bank Indonesia mulai tahun 2003 menunjukan adanya pembiayaan salam beserta volumenya pada setiap laporan tahunan. Namun, beberapa tahun ini data menunjukkan bahwa akad salam sudah tidak banyak lagi diterapkan diperbankan syariah bahkan dalam jangka waktu 10 tahun ini produk salam porsi nya $0 \%$ dari keseluruhan total pembiayaan yang disalurkan. Hal ini menyebabkan banyak pertanyaan, pasalnya pembiayaan salam ini sangat applicable pada perbankan syariah apalagi ketika diterapkan di sektor pertanian.

Konsep pembiayaan istishna ini adalah jual beli secara cicilan namun barangnya diserahkan di belakang, karena untuk transaksi istishna diperlukan pemesanan terlebih dahulu untuk kemudian diproses pembuatannya. Berbeda dengan salam, untuk pembiayaan ini masih cukup peminatnya meskipun porsi nya apabila dibandingkan dengan total pembiayaan pada bank syariah juga masih sangat kecil.

Perkembangan perbankan syariah khususnya di Indonesia tergolong pesat, namun apabila diperhatikan dari sisi kinerja keuangannya terutama dari sisi profitabilitas masih belum menunjukan pertumbuhan yang cukup bagus. Kondisi ini juga bisa dihubungkan dengan pangsa pasar bank syariah yang masih cukup kecil dibandingkan perbankan nasional. Selain itu terjadi ketimpangan terhadap kinerja bank syariah khususnya ditinjau dari kinerja keuangan diantara masing-masing bank, dimana terdapat beberapa bank yang memiliki pertumbuhan yang cukup baik dari sisi kinerja keuangan, di sisi lain terdapat beberapa bank yang mengalami kondisi stagnan atau tetap pertumbuhannya, bahkan terdapat beberapa diantaranya yang mengalami penurunan kinerja.

Permasalahan dominasi pembiayaan berbasis jual beli pada keseluruhan volume pembiayaan yang disalurkan oleh bank syariah yang bahkan mengungguli jenis pembiayaan berbasis bagi hasil yang merupakan ciri khas dan andalan dari sektor perbankan syariah pun menimbulkan pertanyaan. Ditambah lagi dengan timpangnya porsi pembiayaan untuk jenis pembiayaan yang menggunakan akad jual 
beli menimbulkan suatu pertanyaan tersendiri, yaitu murabahah yang berperan dominan dibandingkan dengan produk berbasis jual beli lain. Dari sisi pembiayaan nya sendiri perlu untuk dikaji apakah porsi yang besar dengan volume yang tinggi atas pembiayaan tersebut mempengaruhi kinerja dari bank syariah atau malah profitabilitas perbankan syariah tidak ada kaitannya dengan volume pembiayaan yang disalurkan?

\section{KERANGKA PEMIKIRAN DAN HIPOTESIS}

Resource based theory merupakan sebuah teori yang menyangkut tentang pengembangan sumber daya perusahaan yang berfungsi dalam menciptakan capability atau kemampuan perusahaan dalam menciptakan keunggulan kompetitif yang berguna dalam memenangkan persaingan pasar. Suatu resource yang bernilai, berarti sumberdaya tersebut harus bisa memberikan kontribusi yang lebih terhadap perusahaan dalam menciptakan kemampuan perusahaan untuk melakukan kinerja terbaiknya.

Cakupan bisnis yang luas dipandang dapat menciptakan keunggulan kompetitif, semakin banyak suatu perusahaan menciptakan dan menawarkan produknya semakin usaha tersebut dapat mengusai pasar. Namun demikian, sumberdaya yang produktif harus dikembangkan untuk dapat meningkatkan keunggulan kompetitif. Dalam industri perbankan syariah produk unggulan yang dapat digunakan sebagai produk andalan salah satu nya adalah produk pembiayaan, produk pembiayaan syariah sendiri mempunyai beberapa jenis yang berbeda ditinjau dari jenis aktivitas yang dilakukan. Penyaluran produk pembiayaan yang tinggi diharapkan dapat meningkatkan penjualan bank syariah, dengan penjualan yang meningkat, sebagai dampaknya adalah kenaikan dalam laba yang diperoleh. Kemampuan dalam menghasilkan laba tersebut disebut tingkat profitabilitas, yang salah satu indikatornya adalah ROA atau return on asset yang mengukur kemampuan bank umum syariah dalam menggunakan asetnya untuk menghasilkan laba bersih. Semakin tinggi nilai ROA, maka perusahaan tersebut semakin efisien dalam menggunakan asetnya dalam menghasilkan laba yang maksimal.

Tingkat preferensi masyarakat yang tinggi terhadap produk-produk pembiayaan bank syariah, akan meningkatkan tingkat penjualan bank syariah. Penjualan yang meningkat volumenya akan berdampak pada kenaikan tingkat laba yang dihasilkan serta 
mengindikasikan kinerja yang baik dalam perusahaan.

Pada umumnya lebih dari $75 \%$ kekayaan bank syariah di gunakan untuk pembiayaan syariah dengan skema murabahah atau jual beli (Muhammad, 2005 dalam Rahman dan Rochmanika, 2012). Banyaknya bank syariah begitu atraktif menawarkan produk pembiayaan komersial lewat pola jual-beli ini. Jenis pembiayaan jual beli merupakan investasi jangka pendek, jauh dari unsur ketidakpastian yang ada pada skema bagi hasil sehingga cenderung berrisiko rendah. Kelebihan yang utama adalah penetapan persentase margin keuntungan (mark up) yang jelas dikemukakan di awal kontrak dapat dilakukan dengan memastikan bank memperoleh keuntungan atas aktivitas pembiayaan yang dilakukan. Dalam menentukan margin keuntungan bank syariah perlu menghitung segala hal yang berkaitan untuk bisa menawarkan produk pembiayaan yang dapat memberikan hasil maksimal untuk perusahaan. Penghitungan rasio biaya operasional yang dikeluarkan atas penyaluran produk pembiayaan tersebut merupakan salah satu faktor penting dalam menentukan margin keuntungan yang akan diberikan dalam pembiayaan. Kemudahan pengelolaan disertai adanya penetapan tingkat keuntungan yang jelas, memungkinkan kemampuan bank syariah dalam menghasilkan laba melalui pendapatan yang berasal dari margin keuntungan atas pembiayaan yang disalurkan. Hal ini menjadikan peningkatan volume pembiayaan jual beli yang disalurkan mempunyai pengaruh terhadap peningkatan profitabilitas bank umum syariah yang diproksi dengan ROA ( Rahman dan Rochmanika, 2012). Namun demikian, menurut data dari statistik perbankan syariah di Indonesia dapat dilihat bahwa tingkat profitabilitas perbankan syariah pertumbuhannya masih dalam kisaran rata-rata atau tidak ada peningkatan yang cukup signifikan setiap periodenya, sedangkan pada sisi pembiayaan murabahah volumenya besar dan cenderung meningkat.

Karim (2010) menyatakan bahwa risiko gagal-serah barang dalam pembiayaan salam dan istishna' dapat diantisipasi oleh bank dengan menetapkan kovenan rasio kolateral 220\% yang lebih tinggi 100\% dibandingkan rasio standar sebesar $120 \%$, selain itu risiko jatuhnya harga barang dapat diantisipasi dengan asumsi jenis pembiayaan ini hanya dilakukan berdasarkan atas kontrak pesanan yang telah ditentukan harganya. Dengan asumsi ini yang mungkin menyebabkan pembiayaan istishna masih 
banyak ditawarkan serta diminati dalam penyaluran dana perbankan syariah melalui pembiayaan. Namun tidak diketahui dengan pasti apakah volume pembiayaan istishna berpengaruh terhadap tingkat profitabilitas ataupun sebaliknya.

Sehingga, hipotesis yang dirumuskan adalah:

H1 :Volume produk pembiayaan murabahah mempunyai pengaruh positif terhadap kinerja bank umum syariah Indonesia.

H2 : Volume produk pembiayaan Istishna mempunyai pengaruh positif terhadap kinerja bank umum syariah Indonesia.

H3 : Volume produk pembiayaan berbasis jual beli mempunyai pengaruh yang signifikan terhadap kinerja bank umum syariah di Indonesia.

\section{METODE PENELITIAN DAN ANALISIS DATA}

\section{A. Metode Penelitian}

Populasi dalam penelitian ini adalah seluruh bank umum syariah di Indonesia dengan metode penentuan sampel menggunakan teknik purposive sampling, sampel diambil dari populasi dengan kriteria sebagai berikut (Kuryanto dan Safruddin, 2008): Bank umum syariah yang terdaftar di
Bank Indonesia selama periode penelitian tahun 2010-2014 dan yang menerbitkan laporan keuangan lengkap, serta tidak melakukan corporate action seperti right issue, merger, akuisisi, stock split, maupun aktivitas lainnya, yang secara signifikan dapat mempengaruhi kondisi keuangan perusahaan. Berdasarkan kriteria di atas dari keseluruhan populasi dapat diambil keseluruhan sebagai objek penelitian sehingga diperoleh 11 bank umum syariah.

Variabel yang digunakan dalam penelitian meliputi : variabel dependen yaitu kinerja bank umum syariah yang diproksi dengan ROA atau return on asset, yang merupakan tingkat laba yang dihasilkan dengan menggunakan sejumlah aset yang dimiliki perusahaan. ROA dapat dihitung berdasarkan volume pertumbuhan laba tahunan dengan saldo rata-rata total asset yang dihasilkan bank umum syariah yang menjadi objek penelitian selama periode tahunan.

Variabel produk pembiayaan jual beli merupakan variabel bebas yang mempengaruhi kinerja bank umum syariah, volume produk pembiayaan yang dihitung adalah berdasarkan saldo pada masingmasing jenis pembiayaan yang dihitung tahunan, yang meliputi: Produk Pembiayaan 
Murabahah (X1) dan Produk Pembiayaan Istishna' (X2).

\section{B. Analisis Data}

a. Pengujian Asumsi Klasik Dalam penelitian ini dilakukan uji asumsi klasik meliputi: uji normalitas, asumsi heteroskedastisitas,multikolinierit as, dan autokorelasi.

b. Model yang digunakan dalam penelitian ini menggunkan model multiple regression analysis .Persamaan regresi moderasi dalam penelitian ini,

$$
\mathrm{Y}=\mathrm{a}+\mathrm{b} 1 \mathrm{X} 1+\mathrm{b} 2 \mathrm{X} 2+\mathrm{e}
$$

c. Pengujian Hipotesis

Pengujian dalam menguji hipotesis dilakukan dengan mengambil nilai koefisien determinasi (adjusted $\mathrm{R}^{2}$ ), serta menggunakan uji signifikansi untuk melihat pengaruh, dan uji $\mathrm{F}$ dan uji t yang digunakan untuk mengetahui pengaruh simultan dan parsial dari variabel serta melihat arah dari pengaruh yang terjadi.

\section{HASIL DAN PEMBAHASAN}

\section{A. Hasil}

\section{Hasil Uji Asumsi Klasik}

\section{Berdasarkan Uji Kolmogorov-} Smirnov di atas dapat diketahui bahwa nilai Asymp Sig. (2-tailed) untuk variabel ROA adalah 0,177 dengan nilai $\mathrm{K}-\mathrm{S}=1,102$. Nilai $\mathrm{p}=0,177>$ tingkat signifikansi $(\alpha=0,05)$, angka tersebut menunjukan bahwa data residual terdistribusi normal. Pada uji multikolinearitas tidak ada variabel independen yang memiliki nilai Tolerance kurang dari 0,10 hal ini berarti tidak adanya korelasi antar variabel independen yang nilainya lebih dari $95 \%$. Perhitungan nilai Variance inflation factor (VIF) juga menunjukan tidak ada variabel independen yang memiliki nilai VIF lebih dari 10. Hal ini dapat disimpulkan bahwa berdasarkan hasil uji multikolinearitas menunjukan tidak adanya masalah multikolinearitas antar variabel independen dalam model regresi.

Uji Park Gleyser menunjukan angka probabilitas signifikansinya yaitu 0,239 dan 0,525 yang di atas tingkat kepercayaan $(0,05)$. Hasil pengujian di atas menunjukan bahwa model regresi tidak mengandung Heteroskedastisitas.

Hasil Breusch-Godfrey (B-G Test) menunjukan bahwa nilai $\mathrm{R}^{2}$ sebesar 0,104 . Nilai $X^{2}$ hitung sebesar $(51 \times 0,104)=$ 5,304. Sedangkan nilai $X^{2}$ tabel dengan $\operatorname{df}(2 ; 0,05)$ sebesar 5,991. Karena nilai $X^{2}$ hitung $(5,304)<X^{2}$ tabel $(5,991)$ maka 
model persamaan tidak mengandung masalah autokorelasi.

\section{Hasil Analisis Pengaruh} Tabel 4.1 Hasil Uji Hipotesis

\begin{tabular}{lccc}
\hline Variabel & \multicolumn{3}{c}{ Model ROA } \\
\cline { 2 - 4 } & Koef & T & Sig \\
\hline (Constant) & 1,211 & 4,943 & 0,000 \\
Murabahah & $-3,138$ & $-1,190$ & 0,239 \\
Istishna & 1,808 & 2,050 & $0,046^{* *}$ \\
\hline F & & & \\
Sig F & & 2,149 & \\
Adj R & & & \\
& & 0,127 & \\
& & 0,042 & \\
& & &
\end{tabular}

a. Uji Determinasi

Berdasarkan data yang ada pada table 4.1 ditunjukan nilai adjusted $R$ square sebesar 0.042 . Hal ini berarti bahwa variasi kinerja keuangan (profitabilitas) dapat dijelaskan oleh variasi pembiayaan murabahah dan istishna sebesar $4,2 \%$ atau variabel pembiayaan murabahah dan istishna dapat mempengaruhi profitabilitas bank syariah dengan persentase yang sangat kecil yaitu $4,2 \%$.

b. Uji Pengaruh secara Simultan

Nilai F hitung seperti yang terlihat pada tabel di atas adalah sebesar 2,149 sedangkan nilai $\mathrm{F}$ tabel nya adalah 3,183 , sehingga $F$ hitung $(2,149)<$ nilai $F$ tabel $(3,183)$. Sedangkan nilai nilai signifikansi dari $\mathrm{F}$ adalah 0,127 yang melebihi nilai $\alpha$ nya yaitu 0,05 . Sehingga dapat disimpulkan bahwa variabel bebas secara simultan yang dalam hal ini adalah variabel pembiayaan berbasis jual beli tidak mampu menjelaskan perubahan pada variabel dependen, dan persamaan regresi atau model tidak masuk kriteria kecocokan.

c. Uji Pengaruh secara Parsial

Uji pengaruh yang pertama adalah untuk variabel murabahah terhadap kinerja, diperoleh nilai t hitung sebesar $-1,190>$ dari nilai $\mathrm{t}$ tabel $-1,676$, dimana nilai $\mathrm{t}$ tabel diambil berdasarkan tingkat siginifikansi 1 tailed dengan tingkat signifikansi 0,05 karena pada hipotesis sudah disebutkan arahnya. Selain itu nilai signifikansi untuk variabel murabahah adalah $0,239>$ nilai signifikansi $(\alpha=0,05)$ yang artinya variabel murabahah tidak berpengaruh signifikan terhadap variabel kinerja dan pengaruh yang diberikan adalah negatif.

Uji pengaruh variabel yang kedua adalah istishna, dimana nilai t hitung sebesar $2,050>$ nilai t tabel yaitu 1,676. Selain itu nilai signifikansi nya adalah 0,046 < 0,05. Sehingga dapat disimpulkan variabel istishna mempunyai pengaruh signifikan terhadap variabel kinerja dan pengaruhnya positif.

d. Model Regresi

Hasil uji asumsi di atas menunjukan data yang tersedia memenuhi syarat untuk 
menggunakan model regresi linier berganda.

Tekhnik analisis dalam penelitian ini yaitu model regresi berganda karena model regresi berganda merupakan salah satu uji statistik yang tepat untuk digunakan.

Persamaan model berdasarkan hasil dalam penelitian ini adalah sebagai berikut:

$\mathrm{Y}=1,211-3,138 \mathrm{X}_{1}+1,808 \mathrm{X}_{2}+\mathrm{e}$

\section{B. Pembahasan}

Berdasarkan hasil pengujian statistik terhadap data menunjukan bahwa volume pembiayaan murabahah tidak mempunyai pengaruh yang siginifikan terhadap kinerja keuangan dan pengaruhnya adalah negatif. Hal ini berarti setiap peningkatan terhadap volume pembiayaan murabahah yang disalurkan terhadap masyarakat malah justru akan meberdampak negatif terhadap tingkat profitabilitas meskipun pengaruhnya tidak begitu besar, dapat disimpulkan juga bahwa peningkatan dalam volume pembiayaan murabahah yang disalurkan akan mengakibatkan penurunan terhadap kemampuan bank syariah dalam menghasilkan keuntungan. Ironis dengan pertumbuhan volume pembiayaan murabahah yang sangat pesat dalam sistem perbankan syariah Indonesia khususnya. Pembiayaan murabahah pada bank syariah adalah sama halnya dengan penjualan secara kredit pada perbankan secara umum (piutang), dimana secara teori seharusnya penjualan yang tinggi akan dapat berdampak pada peningkatan pada tingkat laba yang dihasilkan. Pengaruh negatif pembiayaan murabahah juga sejalan dengan penelitian dari Maya (2009) dalam Rahman dan Rochmanika (2012) yang menyatakan bahwa pembiayaan murabahah mempunyai pengaruh yang negatif terhadap kinerja bank syariah, begitu juga dengan Reinissa (2015) yang menyatakan bahwa pembiayaan murabahah berdampak pada penurunan tingkat profitabilitas.

Murabahah umumnya adalah jenis pembiayaan yang digunakan sebagai jenis pembiayaan utama pada bank syariah, dikarenakan pendapatan mark up (margin) yang ditentukan pada awal menyebabkan dapat dilakukannya antisipasi kerugian dari awal pembiayaan. Hasil yang negatif tersebut dapat terjadi apabila terjadi kebangkrutan atau kerugian yang berada pada pihak pembeli, sehingga menyebabkan kemungkinan adanya pembiayaan yang bermasalah (NPF). Pembiayaan murabahah dengan basis pembiayaan jual beli memungkinkan dilakukannya pembiayaan dengan metode kredit (cicilan/angsuran), oleh karena itu pembiayaan bermasalah memungkinkan untuk terjadi pada 
pembiayaan ini. Jadi meskipun tingkat pembiayaan murabahahnya tinggi apabila jumlah pembiayaan yang bermasalah (NPF) juga tinggi akan menyebabkan kurangnya kemampuan dalam menghasilkan laba. Hal ini sejalan dengan penelitian yang dilakukan oleh Arim (2009), Susilawati dan Ali (2012), Purwanto (2011), Adyani(2011) dalam Rahman dan Rochmanika(2012) yang menyatakan bahwa NPF mempunyai pengaruh yang negatif terhadap kinerja laba bank syariah. Ditinjau dari sisi kredit bermasalah yang dalam sistem perbankan konvensional disebut dengan NPL (non performing loan), Nusantara (2009), Gelos (2006) dalam Nusantara (2009), Rahim dan Irpa (2008), Tracey (2011) yang menyatakan bahwa NPL mempunyai pengaruh yang negatif terhadap tingkat profitabilitas. Pengaruh yang negatif yang ditunjukan oleh NPL mengindikasikan bahwa semakin tinggi kredit macet dalam pengelolaan kredit bank yang ditunjukan dalam NPL akan menurunkan tingkat pendapatan bank yang tercermin melalui ROA (Nusantara, 2009).

Faktor biaya juga memungkinkan untuk menjadi penyebab turunnya profitabilitas karena bank syariah di Indonesia saat ini lebih berkonsentrasi pada pengembangan dan perluasan usaha serta yang paling utama adalah untuk dapat survive pada industri perbankan nasional. Bahkan tingkat kepastian keuntungan yang lebih dibandingkan dengan produk lain, tidak juga bisa berpengaruh positif pada tingkat profit yang dihasilkan. Bank syariah cenderung untuk menginvestasikan dana serta mengembangkan diri dengan baik yang tentunya akan berdampak pada pengeluaran biaya yang tinggi tanpa terpengaruh dengan adanya faktor-faktor lain yang terkait dengan tingkat profitabilitas. Pengelolaan biaya operasional yang kurang baik juga berpengaruh terhadap kurangnya laba yang dihasilkan, perlunya pengawasan terhadap seluruh lini kerja bank syariah terkait efisiensi biaya operasional perlu dilakukan. Hasil ini sejalan dengan Rosly dkk (2003) yang menyatakan bahwa penanganan yang baik terhadap rasio biaya overhead akan berpengaruh terhadap tingkat efisiensi bank Islam.

Pengaruh pembiayaan murabahah yang negatif terhadap kinerja keuangan dalam hal likuiditas juga bisa diebabkan karena faktor run off atau penurunan kewajiban murabahah. Prakteknya adalah dimana setiap bulan atau periode mitra mempunyai kewajiban untuk membayarkan hutang pembiayaannya sampai dengan lunas, kemungkinan yang dapt terjadi adalah ketika jumlah penurunan kewajiban akibat 
pembayaran atau perlunasan dipercepat lebih besar volumenya dibandingkan dengan volume pembiayaan murabahah yang baru dibentuk sehingga menyebabkan profit yang seharusnya diperoleh akan berkurang (Reinissa, 2015).

Teori Resource Based Theory dapat kita lihat dari hasil penelitian ini, yaitu ketika penggunaan sumberdaya tidak dilakukan dengan maksimal dalam menciptakan produk. Menurut kriteria, produk berbasis jual beli ini sudah memenuhi kriteria yang "unik" karena merupakan produk khusus dari sistem perbankan syariah yaitu dimana sistem jual beli yang dianut dengan jelas menunjukan maupun menyatakan tingkat margin keuntungan tertentu yang diharapkan berbeda halnya dengan sistem jual beli pada umumnya. Namun demikian, kurangnya tata cara pengelolaan dan belum efektifnya pengimplementasian strategi menyebabkan produk yang bahkan memiliki porsi yang sangat besar dan dominan pada total pembiayaan yang disalurkan tersebut tidak memberi keuntungan lebih terhadap perusahaan.

Berdasarkan hasil pengujian diperoleh kesimpulan bahwa volume pembiayaan dengan akad istishna berpengaruh positif serta berpengaruh signifikan terhadap kinerja bank umum syariah. Hal ini berarti bahwa setiap peningkatan volume dari penyaluran pembiayaan istishna berdampak pada peningkatan kemampuan bank syariah dalam menghasilkan laba. Meskipun istishna merupakan jenis pembiayaan kredit, namun risiko gagal serah barang dapat diminimalkan oleh bank dengan menetapkan tingkat kolateral/ jaminan yang lebih tinggi dari rasio standar, selain itu risiko jatuhnya harga barang juga dapat diminimalkan karena harga sudah ditentukan pada awal pesanan/ kontrak beserta perhitungan margin keuntungan yang dikehendaki dan perhitungan biaya yang sudah diperkirakan dan telah disepakati antara pihak bank dan nasabahnya. (karim,2010)

Hasil ini sesuai dengan RBT theory, dimana pemanfaatan yang tepat atas sumberdaya yang dimiliki perusahaan telah digunakan dengan baik, dengan kriteria sumberdaya yang dimiliki menghasilkan produk unggulan yang digunakan dengan mengimplementasikan strategi yang tepat sehingga menghasilkan kinerja yang baik yang berdampak pada peningkatan keuntungan perusahaan ( bank umum syariah).

Berdasarkan pengujian, hasil yang diperoleh adalah jenis pembiayaan berbasis jual beli tidak mempunyai pengaruh yang 
signifikan terhadap kinerja bank syariah. Pengujian ini dilakukan dengan cara menguji secara bersama-sama jenis pembiayaan berbasis jual beli meliputi : murabahah, salam (dalam hal ini nilainya $=$ 0) dan istishna serta pengaruhnya terhadap kinerja keuangan bank syariah yang diukur dari indikator profitabilitasnya. Basis jual beli sebenarnya bukan merupakan ciri khas dari perbankan syariah, dimana basis utama dari jenis produk bank syariah adalah menggunakan akad bagi hasil. Namun demikian, yang menjadi fenomena adalah porsi pembiayaan berbasis bagi hasil nilainya kurang apabila dibandingkan dengan volume dari pembiayaan berbasis jual beli. Oleh karena itu dilakukan penelitian yang menduga bahwa akad jual beli yang dengan jelas menunjukan margin keuntungan yang diharapkan berpengaruh positif terhadap kemampuan bank syariah dalam menghasilkan laba. Namun pada kenyataannya dengan meneliti bank umum syariah yang terdapat di Indonesia dengan menggunakan data dari periode terkini, diperoleh hasil bahwa akad volume pembiayaan berbasis jual beli justru tidak dapat menjelaskan pengaruhnya terhadap kinerja keuangan bank syariah. Yang berarti bahwa peningkatan dalam jumlah volume pembiayaan berbasis jual beli ketika ditotal ( murabahah, salam dan istishna) tidak mempengaruhi tingkat profitabilitas yang diperoleh oleh bank syariah. Hal ini memerlukan suatu perhatian yang lebih dimana seharusnya volume yang besar dari suatu penjualan harus dapat mendukung kemampuan perusahaan dalam meningkatkan labanya. Efisiensi biaya operasional, serta pengaturan strategi dalam pengkalkulasian tingkat margin keuntungan yang diinginkan diharapkan dapat membuat peningkatan terhadap kemampuan perbankan syariah dakam meningkatkan laba.

\section{KESIMPULAN DAN IMPLIKASI}

Berdasarkan hasil penelitian dan pembahasan, dapat disimpulkan bahwa pembiayaan dengan akad murabahah mempunyai pengaruh negatif serta pengaruhnya tidak signifikan terhadap kinerja bank umum syariah di Indonesia, pembiayaan dengan akad istishna mempunyai pengaruh positif dan pengaruhnya signifikan terhadap kinerja bank umum syariah di Indonesia, sedangkan ditinjau dari basisnya Pembiayaan berbasis jual beli yang merupakan gabungan dari : murabahah dan istishna tidak mempunyai pengaruh yang signifikan terhadap kinerja bank umum syariah di Indonesia. 
Keterbatasan dari penelitian ini adalah penggunaan indikator variabel volume produk pembiayaan berbasis jual beli pada bank syariah dengan tujuan untuk mengetahui jenis pembiayaan yang bervolume besar ini apakah terbukti bisa meningkatkan kinerja bank syariah, namun ternyata jenis pembiayaan ini tinggal 2 produk yang ditawarkan yaitu murabahah dan istishna. Sedangkan pembiayaan salam sudah tidak lagi ada volumenya di bank syariah. Penulis ingin lebih detail lagi dalam menggali informasi tentang pembiayaan salam, hanya saja terdapat keterbatasan informasi, data dan waktu. Karena untuk dapat mencari menelaah lebih tentang jenis pembiayaan yang sudah tidak ditawarkan ini memerlukan survey yang mendalam terhadap objek dan subjek-subjek terkait.

Hasil penelitian ini menunjukkan bahwa jenis pembiayaan berbasis jual beli tidak mempunyai pengaruh yang signifikan terhadap kinerja bank umum syariah. Oleh karena itu diharapkan bank syariah lebih fokus dalam pengembangan produk serta penyalurannya agar setiap jenis pembiayaan yang disalurkan bisa memberikan pengaruh yang positif signifikan atau tepatnya dapat meningkatkan kinerja bank umum syariah, tidak hanya mengedepankan produk yang laku dan simple dalam pelaksanaannya saja.

\section{DAFTAR PUSTAKA}

Akhtar, Muhammad Farhan, dkk. 2011. Factors Influencing the Profitability of Islamic Banks of Pakistan. International Research Journal of Finance and Economics ISSN 1450-2887 Issue 66.

Antonio, Muhammad Syafei. 2001. Bank Syariah: Dari Teori ke Praktik. Gema Insani Press, Jakarta.

Bank Indonesia. Statistik Perbankan Syariah Indonesia (Annual Report Perbankan Syariah Indonesia tahun 2010-2014). Bank Indonesia, Jakarta.

Barney, J.1991. Firm Resource and Sustained Competitive. Jourrnal of Management;Mar 1991;17,1;ABI/INFORM Global pg.99.

Bashir, A.-H. M. 2003. Determinants of Profitabiltiy in Islamic Banks:Some Evidence From The Middle East. Islamic Economic Studies, 11(1), 31-57.

Devi, Abrista. 2013. Analisis Masalah Pembiayaan Salam pada 
Perbankan Syariah di Indonesia. Jakarta.

Grant, Robert, M. 1999. The Resource Based Theory a Competitive Advantage $=$ Implications for Strategy Formulation. California Management Review.

Hanafi, Mamduh M dan Abdul Halim. 2007.

Analisis Laporan Keuangan. Edisi Ketiga. UPP Sekolah Tinggi Ilmu Ekonomi YKPN. Yogyakarta.

Harahap, sofyan syafri. 2004. Akuntansi Islam. PT Bumi Aksara. Jakarta.

Haryono, S, Iman Hilman, dan Abdul Mughits. 2003. Perbankan Syariah Masa Depan. Senayan Abadi Publishing, Jakarta.

Hassan, M. Kabir. 2006. The X-Efficiency in Islamic Banks. Islamic Economic Studies Vol. 13, No. 2.

Hassan, M. Kabir dan Abdel-Hameed M.

Bashir. 2002. Determinants of

Islamic Banking Profitability, ERF paper.

Indriantoro, Nur dan Bambang Supomo. 2002. Metodologi Penelitian Bisnis untuk Akuntansi dan Manajemen. BPFE. Yogyakarta.

Karim, A Adiwarman. 2010. Bank Islam Analisis Fiqih dan Keuangan. Edisi ke 4, Jakarta : Rajawali Pers.
Kasmir. 2003. Manajemen Perbankan. PT

Raja Garafindo Persada. Jakarta.

Khan, Zahoor dkk. 2011. Analysis of the Performance of Islamic and Conventional Banks in Pakistan. Journal of Managerial Sciences. Volume V, Number 1.

Lathif, Ah.Azharuddin. 2012. Konsep dan Aplikasi Akad Murabahah pada Perbankan Syariah di Indonesia. Jakarta.

Machmud, Amir dan H. Rukmana. 2010. Bank Syariah : Teori, Kebijakan dan Studi Empiris di Indonesia. Erlangga. Jakarta.

Nusantara, Ahmad Buyung. 2009. Analisis Pengaruh NPL, CAR, LDR, dan BOPO terhadap Profitabilitas Bank. Tesis UNDIP. Semarang

Peraturan Bank Indonesia Nomor:9/1/PBI/2007 tentang Penilaian Tingkat Kesehatan Bank Umum Berdasarkan Prinsip Syariah.

Prabowo, Bagya Agung. 2009. Konsep Akad Murabahah pada Perbankan syariah (Analisa Kritis terhadap Aplikasi Konsep Akad Murabahah di Indonesia dan Malaysia). Jurnal Hukum No.1 Vol.16 
Rahim, Rida dan Yuma Irpa. 2008. Analisa Efisiensi Operasional terhadap Profitabilitas pada Bus dan UUS.

Reinissa R.D.P, 2013. Pengaruh Pembiayaan Mudharabah, Musyarakah, dan Murabahah terhadap Profitabilitas Bank Syariah Mandiri, Tbk. Skripsi Universitas Brawijaya. Malang

Rikardo. 2011. Perkembangan Prospek Perbankan Syariah Indonesia. http://www.bi.go.id diakses tanggal 19 Oktober 2015.

Rosly, Saiful Azhar dan Mohd Afandi Abu Bakar. 2003. Performance of Islamic and mainstream banks in Malaysia, International Journal of Social Economics, Vol. 30 Iss: 12 pp. $1249-1265$.

Suliyanto. 2011. Ekonometrika Terapan : Teori dan Aplikasi dengan SPSS. Penerbit ANDI. Yogyakarta.

Tracey, Mark. 2011. The Impact of Nonperforming Loans on Loan Growth: an econometric case study of Jamaica and Trinidad and Tobago. Jamaica.

Yaya, Rizal, Aji Erlangga $M$ dan Ahim Abdurahim. 2009. Akuntansi Perbankan Syariah' Teori dan
Praktik Kontemporer'. Salemba Empat. Jakarta. 